\title{
Culture and Female Consciousness behind Changes of Princess Image in Disney Animation
}

\author{
Kexin Wang \\ School of Foreign Languages, Nanjing Normal University, Nanjing 210000, China
}

\begin{abstract}
Movie is not only a product of culture, but also a carrier of culture. And the Disney princess series has been around for more than 80 years, witnessing the rise and fall of history. And the image of princesses has changed greatly. This essay aims at analyzing the relationship between the changes of princesses' images and the development of female consciousness.
\end{abstract}

Keywords: Movie, Images of Disney princesses, Female consciousness.

\section{Introduction}

As the carrier and the product of culture, movies, can to some extent reflect the ethos, mood, or preoccupation of a certain period. Movies do not have a very long history, but just in a few centuries of development, they have achieved a lot. As a mass media, movies not only bring a lot of fun to our lives, but also reflect the cultural needs and changes of the times. When it comes to film companies, the first thing that appears in my mind is the Walt Disney Company, for the images of the princesses in Disney animation are so impressive and unforgettable. The Disney princess series has been around for more than 80 years, witnessing the rise and fall of history.

Today, we are going to talk about these Disney princesses. Over the past century, the image of Disney princesses has changed dramatically both in the shaping of their appearance and in the expression of their words and actions, which is not only a redefinition of femininity, but also a new understanding of female rights to discourse.

\section{Changes of Princess Image}

With fair skin and black hair, Snow White and the Seven Dwarfs entered people's vision in 1937. Snow White, Cinderella, and Aurora, the three white princesses from Western Europe, all had delicate and flawless appearances, and they represented people's expectations of women at that time. In this period, Disney depicts its princess as domestic women who are beautiful and submissive, and stay at home all day to do chores. These stories also regard the princesses as the weak women who need to be rescued by men, and marriage is the only solution to escape from the grief they suffer from.

Thirty years later, in 1989, The Little Mermaid brought princess Ariel from the deep North Atlantic to life. Compared with the traditional image of princess - blonde hair and big eyes, she has burgundy hair, and proved her uniqueness to the world. The former Disney Princess movies mostly, if not all, represent women as the ones who are helpless and require men to save them. However, this representation of women is then altered by Disney, who eventually attempts to change the representation of women into the ones who are independent and able to do things by themselves. (Dita D. Palupi, 2019)
Snow White, Cinderella, and Aurora are elegant, gentle, and beautiful. They represent people's stereotypes of princesses. To be precise, they symbolize the kind of women wanted by society at that time from the perspective of patriarchalism. But the appearance of the little mermaid had a great impact on the traditional princess image with her fearless spirit of adventure. In the underwater world, it is forbidden for a mermaid to make a contact with human, but princess Ariel longs for love and freedom and breaks through this confinement by using her beautiful voice in exchange for legs.

And in Beauty and the Beast (1991), Princess Belle loves reading, which collides with the traditional male rights, for reading is the exclusive privilege of men. In Aladdin (1992), Princess Jasmine escapes from the palace. And then, in the 1990s, the two dark-skinned princesses, Jasmine from Arabia and Merida from North America, also came into our sight. What's more, 1998 witnessed the first Chinese princess, Mu Lan's appearance in Disney. This film is an adaptation of Chinese traditional legend Mulan and tells a story that a girl named Mu Lan, disguised herself as a man to join the army on behalf of her sick and old father. The film adds the element of love in the story which cannot be found in the original story, and it portrays a girl who is brave enough to chase for freedom and love. And we can see from the movie that Mu Lan's motivation is changed from family duty to herself.

Disney presented Frozen in 2013 to celebrate Disney's $90^{\text {th }}$ anniversary. Different from the traditional "princess and prince" model, there are two princesses in the film-Elsa and Anna. It tells a story of ties of kinship. Elsa has the ability of controlling ice and snow but she once hurt Anna accidentally so she fears being with Anna. Anna thought that the prince was her true love, and she tried her best to ask for a kiss but was betrayed by the prince. An act of true love would thaw a frozen heart, but surprisingly, finally it was Elsa's tears rather than the prince's kiss that thawed Anna's frozen heart. It shows that a princess can take her responsibility without the prince's help, apart from love, the princess also has ties of kinship. The princess grows more and more independent.

This trend shows that Disney welcomes cultural diversity and is open to personality differences. Over a century, the images of Disney princesses have made big changes. Princesses are girls from all over the world and now they can get together on 
the stage of Disney. Moreover, they are no longer the sustenance of the beautiful expectations of others, and now they speak for themselves.

\section{Development of Female Consciousness}

The feminist movement, also known as the Women's movement, refers to a series of campaigns for reforms on issues such as reproductive rights, maternity leave, equal pay, sexual violence, and domestic violence. Feminist scholars divided feminism in the USA and western Europe into three waves.

First Wave feminism was during the 1900s and 1920s. In this period, women are campaigning for voting rights. First-wave feminism in America ended with the passage of the Nineteenth Amendment to the United States Constitution (1920), which endowed women with the right to vote in the United States. The feminist movement let women own the social status and rights they deserved, and they left home and began working in society. However, the Great Depression and the Catholic reform movement caused women to go back to domestic life. And the release of Snow White perfectly fitted the image of gentle women who are dependent on men to live and refuse to face the cruel reality. She chose to be a stay-at-home housewife and support her husband and educate children.

Second Wave Feminism was from the early 1960s through the late 1980s, and it focused on other cultural equality issues. And in the early 1960s, many middle-class and upper-class white women began to question their domestic roles. The Women's Movement has led to an unprecedented redefinition of gender images. And in this period, Disney has not continued the princess series.

Influenced by post-modern and post-structuralist thoughts, from the 1990s to the present, the Third Wave Feminism adjusts its focuses from identity and equality to debates around racial differences, social class, and sexuality. In the princess series of the late 1980s and late 1990s, the "love at first sight" model of love was gradually dismantled. It is the princess's own characteristic rather than appearance that brings love to them. Ariel saved the prince's life and her beautiful voice left a deep impression on him. Belle's tolerance and understanding succeeded in opening the lonely heart of the beast prince. Mulan's bravery and intelligence attracted Li Xiang. The mix of all these factors makes the hero fall in love with the heroine, thus forming a beautiful love that resonates with people. The status and appearance of the princesses have been put aside, and their inner values are valued and their personal efforts are recognized, which undoubtedly plays a vital role in making women's voices heard.

In order to expand the market, movies also added new elements. For example, it replaces the traditional fairy tale model with exotic and nostalgic plots. With the development of society, Disney princess movies consciously use the image of new working women to update the image of princesses.
And the new image represents women's responsibility and ambition.

\section{Conclusion}

The transformation of the Disney princess images is a process in which women leave behind a restricted shell of definition and identity and transform into protagonists who can control their own destiny in a male-dominated society. The driving force behind the transformation is not only Disney's in-house producers, but also the development of the feminist movement under the reform of the social system.

\section{References}

[1] Azmi, N.J., Radzuwan Ab Rashid \& Mairas Abd. Rahman. Gender and Speech in a Disney Princess Movie. International Journal of Applied Linguistics \& English Literature. 6(5), 235-239.

[2] Hoerrner, K. L. (1996). Gender roles in Disney films: Analyzing behaviors from Snow White to Simba. Women's Studies in Communication, 19(2), 213-228.

[3] Lacroix, C. (2004). Images of animated others: The orientalization of Disney's cartoon heroines from the Little Mermaid to the Hunchback of Notre Dame. Popular Communication, 2(4), 213-229.

[4] Madeline Streiff, Lauren Dundes. From Shapeshifter to Lava Monster: Gender Stereotypes in Disney's Moana. Social Sciences, 6(3), 91-103.

[5] He M. (2020). An Analysis of the Disney Movie Mulan from the Perspective of Chinese and Western Culture. [J] Radio\&TV Journal, 07: 112-113.

[6] Han X. (2020). Mulan: Disney's Princess and Family-country Imagination. [J] Film Art, 06: 65-68.

[7] Li Z. (2021) A Study on the Transmutation of Female Images in Films from Feminist Perspective-Taking the Disney princess series as an example. [J] Radio\&TV Journal, 03:97-99.

[8] Liu H. (2019). From the liberation of individuality to the return to nature - the changes of Elsa's image in Disney's musical animation Frozen. [J] Literature and Art Forum, 12: 187-190. 